\title{
Journal of Innate Immunity
}

\section{Editors-in-Chief}

H. Herwald, Lund

A. Egesten, Lund

\section{Editorial Board}

B. Beutler, La Jolla, Calif.

N. Borregaard, Copenhagen

V. Brinkmann, Berlin

G.D. Brown, Aberdeen

B. Dahlbäck, Malmö

F.R. DeLeo, Hamilton, Mont.

J. Hoffmann, Strasbourg

M. Holub, Prague

M. Hornef, Hannover

T. Kaisho, Yokohama City

J.D. Lambeth, Atlanta, Ga.

G. McFadden, Gainsville, Fla.

E. Medina, Braunschweig

A. Mowat, Glasgow

P.M. Murphy, Bethesda, Md.

V. Nizet, La Jolla, Calif.
J.E. Pease, London

J. Potempa, Krakow

C.S. Reiss, New York, N.Y.

J.A. Russell, Vancouver, B.C.

D. Schneider, Stanford, Calif.

J.-M. Schröder, Kiel

T. Seya, Sapporo

O. Soehnlein, Munich

C. Speth, Innsbruck

A.N. Theofilopoulos, La Jolla, Calif.

U. Theopold, Stockholm

J.A.G. van Strijp, Utrecht

M.A. Williams, Bethesda, Md.

V. Witko Sarsat, Paris

M.A. Zasloff, Washington, D.C. 


\section{Journal of Innate Immunity}

No. 1

Editorial

1 Of DAMPs and Macrophages

Herwald, H.; Egesten, A. (Lund)

Research Articles

2 The Major Leukocyte Chemotactic and Activating Factors in the Mouse Gut Lumen Are Not N-Formylpeptide Receptor 1 Agonists

Ojode, T.; Schneider, E.H.; Tiffany, H.L.; Yung, S.; Gao, J.-L.; Murphy, P.M. (Bethesda, Md.)

15 Differential Regulation by Toll-Like Receptor Agonists Reveals That MCPIP1 Is the Potent Regulator of Innate Immunity in Bacterial and Viral Infections

Blazusiak, E.; Florczyk, D.; Jura, J. (Krakow); Potempa, J. (Krakow/ Louisville, Ky.); Koziel, J. (Krakow)

24 Extracellular DNA within a Nontypeable Haemophilus influenzae-Induced Biofilm Binds Human Beta Defensin-3 and Reduces Its Antimicrobial Activity

Jones, E.A.; McGillivary, G.; Bakaletz, L.O. (Columbus, Ohio)

39 Bacterial Stimulation of the TLR-MyD88 Pathway Modulates the Homeostatic Expression of Ileal Paneth Cell $\alpha$-Defensins Menendez, A.; Willing, B.P.; Montero, M.; Wlodarska, M.; So, C.C.; Bhinder, G.; Vallance, B.A.; Finlay, B.B. (Vancouver, B.C.)

50 Francisella Is Sensitive to Insect Antimicrobial Peptides Vonkavaara, M.; Pavel, S.T.I.; Hölzl, K.; Nordfelth, R.; Sjöstedt, A.; Stöven, S. (Umeå)

60 Replication of Respiratory Syncytial Virus Is Inhibited by the Host Defense Molecule Viperin

McGillivary, G.; Jordan, Z.B.; Peeples, M.E.; Bakaletz, L.O. (Columbus, Ohio)

72 Involvement of the P2X, Purinergic Receptor and c-Jun $\mathrm{N}$-Terminal and Extracellular Signal-Regulated Kinases in Cyclooxygenase-2 and Prostaglandin $\mathrm{E}_{2}$ Induction by LL-37 Chotjumlong, P. (Chiang Mai); Bolscher, J.G.; Nazmi, K. (Amsterdam); Reutrakul, V. (Bangkok); Supanchart, C.; Buranaphatthana, W.; Krisanaprakornkit, S. (Chiang Mai)

84 TLR7 Contributes to the Rapid Progression but Not to the Overall Fatal Outcome of Secondary Pneumococcal Disease following Influenza A Virus Infection

Stegemann-Koniszewski, S. (Braunschweig/Essen); Gereke, M. (Braunschweig/Magdeburg); Orrskog, S. (Stockholm); Lienenklaus, S.; Pasche, B. (Braunschweig); Bader, S.R.; Gruber, A.D. (Berlin); Akira, S. (Osaka); Weiss, S. (Braunschweig); Henriques-Normark, B. (Stockholm); Bruder, D. (Braunschweig/Magdeburg); Gunzer, M. (Essen)
No. 2

\section{Systems Biology in Innate Immunity}

Edited by Scott D. Kobayashi and Frank R. DeLeo

Editorial

97 Systems Biology and Innate Immunity Kobayashi, S.D.; DeLeo, F.R. (Hamilton, Mont.)

Clinical Investigation

100 Serum Acute Phase Protein and Inflammatory Cytokine Network Correlations: Comparison of a Pre-Rheumatoid Arthritis and Non-Rheumatoid Arthritis Community Cohort Masi, A.T.; Rehman, A.A.; Elmore, K.B.; Aldag, J.C. (Peoria, Ill.)

Research Articles

114 Spatiotemporal Dynamics of Complement C5a Production within Bacterial Extracellular Polymeric Substance

Conrad, E.C. (Ann Arbor, Mich.); Hsu, Y.-Y.; Bortz, D.M. (Boulder, Colo.); Younger, J.G. (Ann Arbor, Mich.)

124 Francisella tularensis Alters Human Neutrophil Gene Expression: Insights into the Molecular Basis of Delayed Neutrophil Apoptosis

Schwartz, J.T.; Bandyopadhyay, S. (Iowa City, Iowa); Kobayashi, S.D. (Hamilton, Mont.); McCracken, J. (Iowa City, Iowa); Whitney, A.R.; DeLeo, F.R. (Hamilton, Mont.); Allen, L.-A.H. (Iowa City, Iowa)

137 Identification of Infection- and Defense-Related Genes via a Dynamic Host-Pathogen Interaction Network Using a Candida Albicans-Zebrafish Infection Model

Kuo, Z.-Y.; Chuang, Y.-J.; Chao, C.-C.; Liu, F.-C.; Lan, C.-Y.; Chen, B.-S. (Hsinchu)

Review

153 Systems Biology of Circadian-Immune Interactions Mavroudis, P.D.; Scheff, J.D. (Piscataway, N.J.); Calvano, S.E. (New Brunswick, N.J.); Androulakis, I.P. (Piscataway, N.J./ New Brunswick, N.J.)

Research Articles

163 Expression and Functional Characterization of Retinoic Acid-Inducible Gene-I-Like Receptors of Mast Cells in Response to Viral Infection

Fukuda, M.; Ushio, H.; Kawasaki, J.; Niyonsaba, F.; Takeuchi, M.; Baba, T.; Hiramatsu, K.; Okumura, K.; Ogawa, H. (Tokyo)

174 Enhancement of Antigen-Specific Immunoglobulin G Responses by Anti-CD48

Yuan, D.; Guo, Y.; Thet, S. (Dallas, Tex.)

185 Inhibition of Intracellular Bacterial Replication in Fibroblasts Is Dependent on the Perforin-Like Protein (Perforin-2) Encoded by Macrophage-Expressed Gene 1

McCormack, R.; de Armas, L.R.; Shiratsuchi, M.; Ramos, J.E.; Podack, E.R. (Miami, Fla.)

\section{KARGER}

E-Mail karger@karger.com www.karger.com
(C) 2013 S. Karger AG, Basel

Access to full text and tables of contents, including tentative ones for forthcoming issues: www.karger.com/jin_issues 
No. 3

Editorial

195 Neutrophils in the Innate Immunity Conundrum of Cystic Fibrosis: A CFTR-Related Matter?

Witko-Sarsat, V. (Paris)

Reviews

197 Pulmonary Surfactant Protein D in First-Line Innate Defence against Influenza A Virus Infections

Hillaire, M.L.B. (Rotterdam); Haagsman, H.P. (Utrecht);

Osterhaus, A.D.M.E.; Rimmelzwaan, G.F. (Rotterdam); van Eijk, M. (Utrecht)

209 Interferon- $\lambda$ s: Special Immunomodulatory Agents and Potential Therapeutic Targets

Zheng, Y.; Li, H.; Yu, J.; Zhao, H. (Tianjin); Wang, S.E. (Duarte, Calif.); Ren, X. (Tianjin)

Research Articles

219 Cystic Fibrosis Transmembrane Conductance Regulator Recruitment to Phagosomes in Neutrophils

Zhou, Y.; Song, K.; Painter, R.G.; Aiken, M. (New Orleans, La.); Reiser, J. (Bethesda, Md.); Stanton, B.A. (Hanover, N.H.); Nauseef, W.M.

(Coralville, Iowa); Wang, G. (New Orleans, La.)

231 Antiviral Innate Immunity Disturbs Podocyte Cell Function Yamashita, M.; Millward, C.A.; Inoshita, H. (Cleveland, Ohio); Saikia, P. (Cleveland, Ohio/Hyderabad); Chattopadhyay, S.; Sen, G.C.;

Emancipator, S.N. (Cleveland, Ohio)

242 Collectin-11/MASP Complex Formation Triggers Activation of the Lectin Complement Pathway - The Fifth Lectin Pathway Initiation Complex

Ma, Y.J.; Skjoedt, M.-O.; Garred, P. (Copenhagen)

251 Staphylococcus aureus Proteases Degrade Lung Surfactant Protein A Potentially Impairing Innate Immunity of the Lung Kantyka, T.; Pyrc, K.; Gruca, M.; Smagur, J.; Plaza, K.; Guzik, K. (Krakow); Zeglen, S.; Ochman, M. (Zabrze); Potempa, J. (Krakow/Louisville, Ky.)

261 Evidence for Specific Genotype-Dependent Immune Priming in the Lophotrochozoan Biomphalaria glabrata Snail

Portela, J.; Duval, D.; Rognon, A.; Galinier, R.; Boissier, J. (Perpignan); Coustau, C. (Nice); Mitta, G.; Théron, A.; Gourbal, B. (Perpignan)

277 Exocytosis of Neutrophil Granule Subsets and Activation of Prolyl Isomerase 1 Are Required for Respiratory Burst Priming McLeish, K.R.; Uriarte, S.M.; Tandon, S.; Creed, T.M.; Le, J.; Ward, R.A. (Louisville, Ky.)

290 The Antimicrobial Peptide LL-37 Alters Human Osteoblast $\mathrm{Ca}^{2+}$ Handling and Induces $\mathrm{Ca}^{2+}$-Independent Apoptosis Säll, J. (Lund); Carlsson, M. (Lund/Malmö); Gidlöf, O.; Holm, A. (Lund); Humlén, J. (Lund/Malmö); Öhman, J.; Svensson, D.; Nilsson, B.-O. (Lund); Jönsson, D. (Lund/Malmö)

No. 4

\section{Trafficking of Innate Immune Cells during Inflammation}

Edited by Oliver Soehnlein

\section{Editorial}

301 Myeloid Cells in Traffic

Soehnlein, O. (Amsterdam/Munich)
Reviews

304 Regulation of Circulating Neutrophil Numbers under Homeostasis and in Disease

Strydom, N.; Rankin, S.M. (London)

315 Damage-Associated Molecular Patterns Control Neutrophil Recruitment

Pittman, K.; Kubes, P. (Calgary, Alta.)

324 Endothelial Junction Regulation: A Prerequisite for Leukocytes Crossing the Vessel Wall

Daniel, A.E.; van Buul, J.D. (Amsterdam)

336 Neutrophil Transmigration: Emergence of an Adhesive Cascade within Venular Walls

Voisin, M.-B.; Nourshargh, S. (London)

348 Tissue-Specific Neutrophil Recruitment into the Lung, Liver, and Kidney

Rossaint, J.; Zarbock, A. (Münster)

358 The Complexity of Arterial Classical Monocyte Recruitment Drechsler, M. (Munich); Soehnlein, O. (Munich/Amsterdam)

367 Control of Myeloid Cell Trafficking in Resolution Norling, L.V.; Perretti, M. (London)

Research Article

377 Regulation of Neutrophil Apoptosis Differs after in vivo Transmigration to Skin Chambers and Synovial Fluid: A Role for Inflammasome-Dependent Interleukin-1 $\beta$ Release Christenson, K.; Björkman, L.; Karlsson, A.; Bylund, J. (Gothenburg)

Research Articles

389 CD300c is an Activating Receptor Expressed on Human Monocytes

Simhadri, V.R.; Mariano, J.L.; Gil-Krzewska, A.; Zhou, Q.; Borrego, F. (Bethesda, Md.)

401 G-Protein-Coupled Receptor Kinase-5 Mediates Inflammation but Does Not Regulate Cellular Infiltration or Bacterial Load in a Polymicrobial Sepsis Model in Mice

Packiriswamy, N.; Lee, T.; Raghavendra, P.B.; Durairaj, H.; Wang, H.; Parameswaran, N. (East Lansing, Mich.)

414 Viral Attachment Induces Rapid Recruitment of an Innate Immune Sensor (TRIM5a) to the Plasma Membrane

Ohmine, S.; Singh, R.D.; Marks, D.L.; Meyer, M.A.; Pagano, R.E.; Ikeda, Y (Rochester, Minn.)

No. 5

Autophagy and Innate Immunity

Edited by Véronique Witko-Sarsat and Patrice Codogno

Editorial

425 Autophagy and Innate Immunity

Witko-Sarsat, V.; Codogno, P. (Paris)

Reviews

427 The Mechanism and Physiological Function of Macroautophagy Klionsky, D.J. (Ann Arbor, Mich.); Codogno, P. (Paris)

434 Autophagy and Crohn's Disease

Nguyen, H.T.T. (Clermont-Ferrand); Lapaquette, P. (Paris); Bringer, M.-A.; Darfeuille-Michaud, A. (Clermont-Ferrand) 
444 Antimicrobial Autophagy: A Conserved Innate Immune Response in Drosophila

Moy, R.H.; Cherry, S. (Philadelphia, Pa.)

456 Pathogen-Induced Autophagy Signaling in Innate Immunity Faure, M. (Lyon); Lafont, F. (Lille)

471 Secretory versus Degradative Autophagy: Unconventional Secretion of Inflammatory Mediators Jiang, S.; Dupont, N.; Castillo, E.F.; Deretic, V. (Albuquerque, N. Mex.)

480 Autophagy and Viruses: Adversaries or Allies? Dong, X.; Levine, B. (Dallas, Tex.)

Research Articles

494 Impairment in Natural Killer Cells Editing of Immature Dendritic Cells by Infection with a Virulent Trypanosoma cruzi Population

Batalla, E.I.; Pino Martínez, A.M.; Poncini, C.V.; Duffy, T.; Schijman, A.G.; González Cappa, S.M.; Alba Soto, C.D.

(Buenos Aires)

505 Highly Pathogenic Influenza Viruses Inhibit Inflammatory Response in Monocytes via Activation of Rar-Related Orphan Receptor RORa

Friesenhagen, J.; Viemann, D. (Münster/Hannover); Börgeling, Y.; Schmolke, M.; Spiekermann, C. (Münster); Kirschnek, S. (Freiburg); Ludwig, S.; Roth, J. (Münster)

519 Midkine Is Part of the Antibacterial Activity Released at the Surface of Differentiated Bronchial Epithelial Cells Nordin, S.L.; Andersson, C.; Bjermer, L. (Lund); Bjartell, A. (Malmö); Mörgelin, M.; Egesten, A. (Lund)

No. 6

Research Articles

531 Colony-Stimulating Factor-1-Responsive Macrophage Precursors Reside in the Amphibian (Xenopus laevis) Bone Marrow rather than the Hematopoietic Subcapsular Liver Grayfer, L.; Robert, J. (Rochester, N.Y.)

543 Nrf2 Deficiency in Dendritic Cells Enhances the Adjuvant Effect of Ambient Ultrafine Particles on Allergic Sensitization Li, N. (East Lansing, Mich./Los Angeles, Calif.); Wang, M.

Barajas, B.; Sioutas, C. (Los Angeles, Calif.); Williams, M.A

(Research Triangle Park, N.C.); Nel, A.E. (Los Angeles, Calif.)
555 Prognostic Value of Endotoxemia in Patients with Gram-Negative Bacteremia Is Bacterial Species Dependent Hurley, J.C. (Ballarat, Vic.); Opal, S.M. (Providence, R.I.)

565 NOX2 Protects against Prolonged Inflammation, Lung Injury, and Mortality following Systemic Insults Whitmore, L.C.; Hilkin, B.M.; Goss, K.L.; Wahle, E.M.; Colaizy, T.T.; Boggiatto, P.M.; Varga, S.M.; Miller, F.J.; Moreland, J.G. (Iowa City, Iowa)

581 Prognostic Value and Therapeutic Potential of TREM-1 in Streptococcus pyogenes-Induced Sepsis

Horst, S.A. (Braunschweig); Linnér, A. (Stockholm); Beineke, A. (Hannover); Lehne, S.; Höltje, C.; Hecht, A. (Braunschweig); Norrby-Teglund, A. (Stockholm); Medina, E.; Goldmann, O. (Braunschweig)

591 Mycobacterium tuberculosis-Induced Neutrophil Extracellular Traps Activate Human Macrophages Braian, C.; Hogea, V.; Stendahl, O. (Linköping)

603 Limited Role of the Receptor for Advanced Glycation End Products during Streptococcus pneumoniae Bacteremia Achouiti, A.; de Vos, A.F.; de Beer, R.; Florquin, S.; van 't Veer, C.; van der Poll, T. (Amsterdam)

613 Effects of ex vivo $\mathrm{Y}$-Tocopherol on Airway Macrophage Function in Healthy and Mild Allergic Asthmatics Geiser, M.; Lay, J.C.; Bennett, W.D.; Zhou, H.; Wang, X.; Peden, D.B.; Alexis, N.E. (Chapel Hill, N.C.)

625 Intestinal Epithelium-Derived Galectin-9 Is Involved in the Immunomodulating Effects of Nondigestible Oligosaccharides

de Kivit, S.; Kraneveld, A.D. (Utrecht); Knippels, L.M.J.

(Utrecht/Wageningen); van Kooyk, Y. (Amsterdam); Garssen, J. (Utrecht/Wageningen); Willemsen, L.E.M. (Utrecht)

639 HIV-1 Nef Interacts with HCV Core, Recruits TRAF2, TRAF5 and TRAF6, and Stimulates HIV-1 Replication in Macrophages Khan, K.A.; Abbas, W.; Varin, A.; Kumar, A.; Di Martino, V.; Dichamp, I.; Herbein, G. (Besançon)

Editors' Choice

657 Macrophages: Past Present, and Future Herwald, H.; Egesten, A. (Lund)
S. Karger

Medical and Scientific Publishers

Basel Freiburg $•$ Paris $\bullet$ London $・$ New York

New Delhi $\bullet$ Bangkok $\cdot$ Beijing $\cdot$ Tokyo $•$

Kuala Lumpur $\cdot$ Singapore $\bullet$ Sydney
Disclaimer

The statements, opinions and data contained in this publication are solely those of the individual authors and contributors and not of the publisher and the editor(s). The appearance of advertisements in the journal is not a warranty, endorsement, or approval of the products or services advertised or of their effectiveness, quality or safety. The publisher and the editor(s) disclaim responsibility for any injury to persons or property resulting from any ideas, methods, instructions or products referred to in the content or advertisements.

Drug Dosage

The authors and the publisher have exerted every effort to ensure that drug selection and dosage set forth in this text are in accord with current recommendations and practice at the time of publication. However, in view of ongoing research, changes in government regulations, and the constant flow of information relating to drug therapy and drug reactions, the reader is urged to check the package insert for each drug for any change in indications and dosage and for added warnings and precautions. This is particularly important when the recommended agent is a new and/or infrequently employed drug.
All rights reserved.

No part of this publication may be translated into other languages, reproduced or utilized in any form or by any means, electronic or mechanical, including photocopying, recording, microcopying or by any information storage and retrieval system, without permission in writing from the publisher or, in the case of photocopying, direct payment of a specified fee to the Copyright Clearance Center (see 'General Information').

(c) Copyright $2012 / 2013$ by S. Karger AG,

$\mathrm{CH}-4009$ Basel (Switzerland)

Printed on acid-free and non-aging paper (ISO 9706) 